\title{
AFINIDADES, DIFERENÇAS POLÍTICAS E CONSAGRAÇÃO: UMA ANÁLISE DE CRÍTICAS LITERÁRIAS SOBRE ROMANCES FRANCESES EM 1836
}

\author{
ABREU, Márcia ${ }^{1}$ \\ GABRIELLI, Beatriz ${ }^{2}$
}

RESUMO: Este artigo tem por objetivo compreender o modo de funcionamento da crítica literária francesa na avaliação de romances no início do século XIX. Centraremos nossa atenção em dois periódicos - La Presse e Le Constitutionnel - e, mais especificamente em um conjunto de críticas que tem por objeto as mesmas obras e que foram publicadas em ambos os jornais. Evidentemente, o estudo de avaliações produzidas sobre um conjunto reduzido de romances em apenas dois jornais não é suficiente para determinar um perfil das críticas em periódicos. Mas as características peculiares do material (diferenças políticas entre os jornais, distintos graus de consagração dos autores e diverso prestígio dos comentadores) poderão trazer uma compreensão mais acurada sobre o modo de funcionamento da crítica francesa na primeira metade do século XIX, tema ainda pouco explorado. Nosso propósito é responder a algumas questões: o perfil político dos jornais afeta o julgamento dos romances? O grau de consagração dos autores interfere nas opiniões? As relações entre os letrados têm impacto nas avaliações?

PALAVRAS-CHAVE: crítica literária, periódicos, França, romance, século XIX

\section{AFFINITIES, POLITICAL DIFFERENCES AND CONSECRATION: AN ANALYSIS OF LITERARY CRITICISM ABOUT FRENCH NOVELS IN 1836}

\begin{abstract}
This article aims to understand how French literary criticism operates in the evaluation of novels in early 19th century. We will focus our attention on two periodicals - La Presse and Le Constitutionnel - and, more specifically, on a set of analysis, which have as their object the same novels,

\footnotetext{
${ }^{1}$ Professora Livre Docente do Departamento de Teoria Literária, do Instituto de Estudos da Linguagem da Unicamp. A pesquisa da qual resulta esse artigo foi financiada pelo CNPq. <marcia.a.abreu@gmail.com>

${ }^{2}$ Mestre em Teoria e História Literária pelo Instituto de Estudos da Linguagem da Unicamp. Pesquisa financiada pelo CNPq. <beatriz.gabrielli1@ gmail.com>
}

Jangada | nr. 16, jun/dez, 2020 | ISSN 2317-4722 162 |P á g i n a 


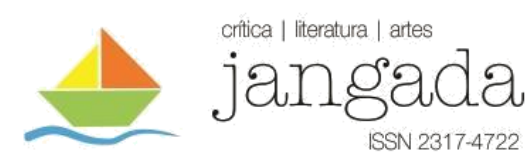

and which were published in both newspapers. Obviously, the study of critics about a reduced set of novels in just two newspapers is not enough to determine a profile of criticisms in periodicals. However, the peculiar characteristics of the material (political differences between the newspapers, different degrees of consecration of the authors and the different prestige of the commentators) may bring a more accurate understanding of the way French criticism works in the first half of the 19th century, a topic insufficiently explored yet. Our purpose is to answer some questions: does the political profile of newspapers affect the judgment of novels? Does the authors' consecration degree interfere in the judgments? Do the relationships between the critics have an impact on evaluations?

KEYWORDS: literary criticism, periodicals, France, novel, 19th century

\section{INTRODUÇÃO}

Na primeira metade do século XIX, a crítica literária periodística engatinhava, mesmo na França, centro da república mundial das Letras (CASANOVA, 2002, p. 40). Nos periódicos, o espaço do folhetim e o das variedades era ocupado com comentários sobre peças teatrais e musicais, sobre acontecimentos sociais, bem como com a publicação parcelada de romances. Todos eles recebiam mais espaço do que a crítica sobre obras literárias, especialmente se forem considerados os romances.

Ainda em processo de estabelecimento, a crítica era marcada por sua periodicidade irregular e pela não especialização de seus autores. Os próprios críticos acreditavam que a publicação fragmentada e o espaço restrito impediam que colocassem seu estilo pessoal nos textos e avaliassem as obras satisfatoriamente. Havia também quem os reprovasse por considerá-los pouco sérios em suas críticas, desconfiando do fato de que muitos deles tinham aspirações literárias próprias e, portanto, interesses pessoais que poderiam interferir em suas avaliações (MELMOUX-MONTAUBIN, 2011, p. 937). Essa desconfiança se fazia presente ao menos desde 1829, quando o jornalista Henri de Latouche publicou na Revue de Paris um texto intitulado "De la camaraderie littéraire", no qual denunciou a constante bajulação entre os membros do Cenáculo, grupo de escritores liderado por Victor Hugo, cujas reuniões seriam destinadas a inflar o ego de seus participantes com comentários sempre positivos, a fim de obter favores e subir na hierarquia do grupo (LATOUCHE, 1829). Os próprios jornais também comprometeriam a integridade da crítica ao favorecer anunciantes, visando a aumentar seus lucros, como denunciou o crítico Sainte-Beuve em seu famoso texto "De la littérature industrielle" (1839). A dependência com relação aos livreiros anunciantes e o fato de os autores 
de críticas serem também escritores conduziriam a avaliações muito amigáveis (THÉRANTY; VAILLANT, 2001, p. 68-69), o que teria efeitos nefastos sobre a literatura e sobre a moralidade, visto que os erros (de forma e conteúdo) não seriam denunciados (GLINOER, 2009, p. 2).

A soma desses fatores, aliada à escassa produção crítica, não favoreceu a realização de pesquisas sobre a recepção de romances na imprensa no começo do Oitocentos. Este artigo tem por objetivo olhar para essa produção a fim de compreender o modo de funcionamento da crítica na avaliação das obras ficcionais. Na impossibilidade de considerar toda a imprensa, centraremos nossa atenção em dois importantes periódicos franceses - La Presse e Le Constitutionnel. Analisaremos, mais especificamente, um conjunto de críticas publicadas em ambos os periódicos em 1836, voltadas aos mesmos romances, com o propósito de responder a algumas questões: o perfil político dos jornais afetaria o julgamento das obras? o grau de consagração dos autores interferiria nas opiniões? as relações entre os letrados teriam impacto nas avaliações?

De um total de 87 críticas (das quais 43 no Le Constitutionnel e 44 no La Presse), que comentam 91 romances (70 deles no Le Constitutionnel e 21 no La Presse), publicadas entre 1836 e 1850, apenas cinco dizem respeito aos mesmos romances: Le Chemin de Traverse, de Jules Janin, Une Couronne d'Épines, de Michel Masson, Le Notaire de Chantilly ou les Influences, de Léon Gozlan, Picciola, de X.-B. Saintine e Sathaniel, de Frédéric Soulié. Todos eles foram publicados e comentados em 1836, momento inicial da produção de romances em folhetim na França ${ }^{3}$, escritos por autores com diferentes níveis de importância e comentados em data próxima ao lançamento.

Evidentemente, o estudo de avaliações produzidas sobre cinco romances em dois jornais não é suficiente para determinar um perfil das críticas em periódicos. Mas as características peculiares do material (diferenças políticas entre os jornais, distintos graus de consagração dos autores e o diverso prestígio dos comentadores) poderão trazer uma compreensão mais acurada sobre o modo de funcionamento da crítica francesa na primeira metade do século XIX, tema ainda pouco explorado. ${ }^{4}$

\footnotetext{
${ }^{3}$ Convencionou-se datar o início da publicação de romances em folhetim com La Vieille Fille, narrativa de Balzac saída à luz no La Presse, em 1836, ainda que, como mostra Marie-Ève Thérenty, "Existam ficções anteriormente presentes no La Presse as quais atendem melhor do que La Vieille Fille à poética do romance folhetim." ("Il existe des fictions antérieurement parues dans La Presse qui répondent mieux que La Vieille fille à la poétique du romanfeuilleton.”). (THÉRENTY, 2003, p. 628-629)

${ }^{4} \mathrm{O}$ conjunto de textos críticos que abordaram romances e que foram publicados no La Presse e no Le Constitutionnel foi estudado em GABRIELLI, 2018.
} 


\section{OS PERIÓDICOS}

A imprensa francesa passou por transformações profundas no século XIX. O processo de revolução midiática rumo à massificação, como caracterizou Judith Lyon-Caen, teve como símbolo o periódico de Émile de Girardin, La Presse, Journal quotidien, politique, littéraire, agricole, industriel et commercial, que iniciou suas atividades em 1836 e permaneceu ativo até 1928 (LYON-CAEN, 2011).

La Presse custava um sou (cinco centavos de franco) por edição e sua subscrição anual saía por 40 francos, metade do habitualmente cobrado pelos outros jornais (KALIFA; RÉGNIER; THÉRENTY; VAILLANT, 2011, p. 12). O preço mais baixo possibilitou que leitores de menor poder aquisitivo tivessem acesso a ele, embora o valor ainda pesasse no bolso dos menos privilegiados, já que a assinatura anual correspondia à remuneração por 210 horas de ofício de um trabalhador braçal à época (LYON-CAEN, 2011, p. 24).

A publicação buscava ser política e economicamente independente, sustentando-se com a renda das vendas e dos anúncios (KALIFA; RÉGNIER; THÉRENTY; VAILLANT, 2011, p. 12). Apesar de não ter vínculos reconhecidos com partidos políticos, Émile de Girardin tinha aspirações políticas e usava a publicação para promover suas ideias, defender aliados e criticar inimigos. A estratégia parece ter surtido efeito, visto que ele foi eleito deputado em 1834 e reeleito mais quatro vezes por diferentes departamentos franceses ao longo da Monarquia de Julho e da Segunda e da Terceira Repúblicas. Suas posições políticas oscilaram ao longo de seus mandatos, iniciando como um conservador com algumas ideias progressistas contra o rei Luís Felipe e a favor de Luís-Napoleão Bonaparte, para, em seus últimos anos, alinhar-se à extrema-direita republicana (WATELET, 1990, p. 358).

La Presse era composto por quatro páginas com três colunas de texto, além de um rodapé, que ocupava as duas primeiras páginas, em que se publicavam textos de variedades sobre festas, apresentações teatrais e musicais, além de críticas a livros, publicação de romances e de dramaturgia. Suas primeiras páginas eram dedicadas a notícias políticas e econômicas, especialmente sobre a França, mas também sobre outros países europeus e sobre as colônias francesas. Na terceira página, havia espaço para assuntos variados, como críticas de livros, ensaios sobre filosofia, literatura e artes. Por fim, a última página era dedicada a anúncios, com algumas notas sobre serviços, movimento de navios nos portos etc. Os textos críticos poderiam figurar em qualquer das páginas do jornal. 


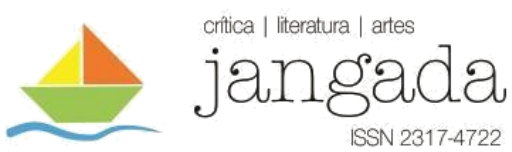

O principal fator de atração de leitores, além do baixo preço, foi a publicação de romances em folhetim, iniciada com La Vieille Fille, encomendado especialmente por Girardin a Balzac, e publicado a partir de 23 de outubro de 1836. A ampliação das tiragens dá a medida da boa aceitação das inovações, passando de pouco mais de 13400 exemplares para 63000 . Em seu primeiro ano, La Presse tornou-se o terceiro jornal mais adquirido pelos franceses, atrás apenas do seu rival direto Le Siècle e do Journal des Débats (LYON-CAEN, 2011, p. 24).

O sucesso do La Presse afetou os jornais tradicionais, entre os quais Le Constitutionnel (FEYEL, 2011, p. 97). Fundado sob o nome de L'Indépendant, em 1815, esteve sob a liderança de Antoine Jay, seu redator principal. Desde o início, o periódico sofreu perseguições por seu alinhamento político de esquerda liberal, sendo a favor de Bonaparte no poder. O empenho em defender seus ideais políticos rendeu ao jornal censuras e pausas em suas atividades, trocando de nome a cada interrupção. De L'Indépendant passou a L'Echo du Soir, depois a Le Courrier, para assumir, ainda em 1815, o título pelo qual ficaria conhecido, Le Constitutionnel, journal du commerce, politique et littéraire (BRISSON; RIBEYRE, 1862, p. 293-5). Após quase cem anos de atividade, a publicação chegou ao fim em 1914.

A distribuição de espaço em Le Constitutionnel era semelhante à do La Presse. Com quatro páginas divididas em três colunas, reservava-se o rodapé das duas primeiras às variedades sobre o mundo artístico parisiense e aos textos de opinião de seus redatores. Notícias sobre a França e sobre o mundo, assim como assuntos políticos e econômicos ocupavam as primeiras páginas, enquanto a última abrigava anúncios. O local de inserção dos textos críticos não era fixo, podendo aparecer logo na primeira página ou situar-se em meio a assuntos diversos, em alguma coluna no corpo do jornal (GABRIELLI, 2018).

Embora tenha sido o principal periódico francês na década de 1820, o advento do “journal à bon marché” enfraqueceu sua posição, especialmente no que diz respeito às vendas (FEYEL, 2011). O caminho encontrado para recuperar espaço foi a publicação de folhetins, iniciada em 1844 com Le Juif errant, de Eugène Sue, ao qual se seguiram sucessos assinados por Alexandre Dumas pai, George Sand, Balzac e pelo próprio Sue. Os números mostram que a empreitada foi bem-sucedida, ampliando o número de assinantes para 23000 ao longo da publicação de seu primeiro romance em folhetim (KALIFA; RÉGNIER; THÉRENTY; VAILLANT, 2011, p. 12). Mas, no momento em que foram publicadas as críticas aqui analisadas, Le Constitutionnel ainda contava com público mais restrito, entre outros motivos pelo valor da assinatura: 20 francos por 3 meses, 40 pelo semestre e 80 pelo ano (Le Constitutionnel, 02/05/1836, p. 1), ou seja, o dobro do que cobrava o La Presse. 
Assim, os periódicos apresentavam posições políticas e trajetórias distintas. Em 1836, Le Constitutionnel ocupava um espaço de relevo na imprensa francesa e alinhava-se à esquerda; La Presse era um recém-chegado, que trazia inovações no preço e nas estratégias para atrair o público e possuía uma visão política mais conservadora. Teria isso feito alguma diferença no posicionamento dos críticos diante de um mesmo conjunto de romances?

\section{OS ROMANCISTAS E OS CRÍTICOS}

Os autores das obras analisadas tinham bastante em comum, ainda que com algumas peculiaridades. Eles eram praticamente da mesma idade: Janin, o mais jovem deles, tinha 32 anos, Gozlan, 33, Masson e Soulié, 36, e Saintine, 38. Todos faziam parte do grupo de letrados atuantes em Paris, com presença na imprensa e contatos no mundo editorial; Janin, Masson, Soulié e Saintine publicaram seus romances com o mesmo editor, Ambroise Dupont.

No entanto, seu reconhecimento e sua posição na carreira eram um pouco distintos. Janin tinha ingressado nas letras como crítico dramático, em 1824, passando, ainda na década de 1820, para o jornalismo político, com colaboração em jornais menores como Le Figaro e La Quotidienne, até chegar em 1829 ao Journal des Débats, onde voltou às variedades. Tornou-se conhecido em 1827 com o romance L'Âne mort et la femme guillotinée e consolidou seu papel como crítico. Em 1836, já era influente, atuava regularmente em periódicos de destaque e tinha publicado vários livros, alguns dos quais com muitas edições, indicando sucesso de público (JOUKOVSKY, 1974, p. 31).

Masson tinha uma prolífica produção, especialmente para o teatro, tendo atuação também na imprensa periódica. Seu primeiro romance, Le Maçon, foi escrito em colaboração com Raymond Brucker, publicado sob pseudônimo de Michel Raymond em 1829, e bastante elogiado pela crítica. Curiosamente, Gozlan também escreveu em parceria com Raymond Brucker, com quem publicou seu primeiro romance, Les Intimes, em 1834, sob o mesmo pseudônimo de Michel Raymond. Ele se dedicou ao teatro e teve atuação na imprensa periódica como os demais, mas com um pouco menos de destaque (THÉRENTY, 2007).

Soulié havia publicado poemas e romances, escrito peças de teatro e atuava regularmente na imprensa. Seu nome era já bastante conhecido como autor de obras de sucesso e se tornaria ainda mais festejado no ano seguinte com a publicação de Mémoires du diable. Além de romancista, era crítico e, entre outras muitas atividades, preparava comentários a obras literárias para o La Presse. A partir de 1837, sua atuação no periódico deixaria de se ligar à 
crítica e passaria aos romances em folhetim, com os quais fez fama (CHAMPION, 1847, p. 14$31)$.

Saintine era o nome com o qual Joseph-Xavier Boniface assinava suas peças teatrais e romances. Ele era bastante conhecido, tendo publicado quase uma dezena de livros, entre obras poéticas, dramáticas e ficcionais. Em 1820, ganhou o prêmio de poesia da Academia Francesa com o poema L'enseignement mutuel (BIRÉ; GRIMAUD, 1865, p. 253). Entretanto, seu maior êxito foi Picciola, a obra com a qual se tornou conhecido na Europa.

Não apenas os romancistas tinham pontos de contato e semelhanças. Os letrados responsáveis pelas avaliações também os tinham, a começar pelo fato de que um deles, Frédéric Soulié, era, ao mesmo tempo, autor de crítica e de romance criticado. Mas havia também diferenças notáveis entre eles. Se Soulié gozava de prestígio, como crítico e como escritor, o autor das avaliações publicadas no Le Constitutionnel sequer apresentava seu nome - o que era bastante usual, já que a atividade de folhetinista era considerada pouco séria e malvista pelos outros críticos e homens de letras (MELMOUX-MONTAUBIN, 2003). Ele assinava sob o pseudônimo de I.C.T., que, segundo o Dictionnaire des ouvrages anonymes de Barbier (1872, p. 733), corresponde a M. L. Raybaud, homem de letras de pequeno reconhecimento e colaborador assíduo do Le Constitutionnel. Em 1833, ele havia lançado uma "ode marinha" intitulada Le négrier que recebeu pequena nota na Revue de Paris (1832, p. 59). Sua carreira prosseguiu sem muito destaque, com a publicação de obras sobre as diferentes "raças humanas" (REYBAUD, 1837), sobre agricultura, sobre a colonização da Argélia etc (REYBAUD, 1850). Não foi possível localizar a data de seu nascimento para saber se ele pertencia à mesma geração dos romancistas, mas é possível que sim, tendo em vista a data de publicação de suas obras. Ainda mais desconhecido é Alphonse Rastoul, que publicou apenas uma crítica a livro no $L a$ Presse, o comentário a Sathaniel. Ele era autor de obras históricas e de biografias de monarcas, artistas e escritores, além de ter sido professor de literatura e história no liceu de Avignon, cidade onde tinha atuação na imprensa, assim como em Lyon (LIESEN, 1990, p. 113). Conheceu algum sucesso com seus trabalhos de historiografia Les Manteaux-Rouges (RASTOUL, 1831) e Léopold $I^{e r}$, Roi des Belges (RASTOUL, 1850). Nascido em 1800, tinha exatamente a mesma idade de Fréderic Soulié, seu companheiro no La Presse e autor do romance por ele analisado.

\section{OS ROMANCES}




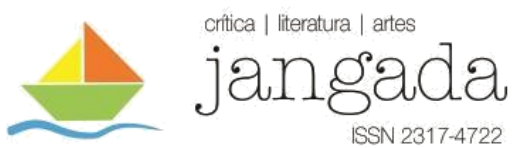

Cronologicamente, o primeiro romance a receber atenção dos críticos foi Le Chemin de Traverse, de Jules Janin. O livro, publicado por Ambroise Dupont, foi um sucesso de vendas, chegando a ter quatro edições no ano de seu lançamento. ${ }^{5}$ Narra a história de Prosper Chavigny, filho de um fazendeiro que, por sua saúde frágil, se torna um homem de letras, conhecedor do latim e do grego, destacando-se na pequena cidade onde vivia. Buscando reconhecimento, vai para Paris, mas não obtém sucesso, pois, diferentemente do que ocorria em sua cidade natal, ali muitos outros conheciam as letras. Em viagem para a Itália, conhece Letizia, com quem se casa e volta a Paris. Sem recursos e buscando manter seu status, Prosper vende a própria esposa para um nobre, dando início à derrocada da moça, que se torna prostituta. Tempo depois, arrependese e pede o perdão de Letizia, que o aceita, retornando com ele à cidade natal de Prosper. Ele tinha um irmão menos culto, Christophe, que, tendo trabalhado desde a infância no campo, torna-se bem-sucedido após salvar a filha de um duque em um acidente e casar-se com ela. Christophe destaca-se no ducado do sogro por suas virtudes, um destino bastante diferente de seu irmão ambicioso e sem escrúpulos.

Não se pode dizer que Une Couronne d'Épines, de Michel Masson, tenha sido um fracasso. O romance recebeu pelo menos três edições no ano de seu lançamento, pelo editor Ambroise Dupont, além de quatro outras edições fora da França. ${ }^{6}$ A narrativa tem tema semelhante ao do romance de Janin: irmãos com personalidades distintas premiados ou castigados em consequência de seus atos. Richard Savage, rico filho de um conde, deixa sua fortuna e família para dedicar-se à poesia. David Sauveur, irmão desconhecido de Richard, é um jovem comerciante, trabalhador e honrado. Ambos se encontram quando o poeta, que fugia da polícia após ter matado o amante da mãe, busca refúgio no estabelecimento de David, sem saber da ligação entre ambos. Durante sua estadia, Richard apaixona-se por Jane Pretty e é correspondido, frustrando as expectativas de David, que também se interessava pela moça. Richard acaba por ser preso, mas Jane consegue que a Rainha o ajude a fugir com a condição de que vá viver anonimamente em Londres. Orgulhoso e imprudente, ele revela sua identidade para alguns nobres, o que o leva de volta à prisão, onde morre. O virtuoso David, ao contrário, é recompensado com felicidade e bens, sendo reconhecido por seu pai e declarado seu herdeiro. Após anos desaparecida, Jane retorna à cidade e David a acolhe como a irmã que nunca teve.

\footnotetext{
${ }^{5}$ Ver JANIN, J. Le Chemin de Traverse. Quatrième édition entièrement revue et corrigée. Paris: Ambroise Dupont, 1836. (grifo nosso). Em 1842, seis anos depois, anúncio de obras à venda por Jules Chapelle et Compagnie indica que o romance já estava na sétima edição: "Le Chemin de Traverse, par Jules Janin, 1 vol. in $-8^{\circ}, 7^{\mathfrak{e}}$ édition, 5 fr.". (La Presse, 21/05/1842).

${ }^{6}$ Ver indicações das edições nas referências bibliográficas.
}

Jangada | nr. 16, jun/dez, 2020 | ISSN 2317-4722

$169 \mid$ P á g i n a 
Le Notaire de Chantilly ou les Influences, de Léon Gozlan, teve circulação um pouco menor. Foi publicado em Paris, pela Librairie de Dumont, e recebeu publicações em Bruxelas no mesmo ano de seu lançamento. ${ }^{7}$ A narrativa também explora a corrupção moral, focando na ação de Léonide, esposa de Maurice (o notário do título), e na atuação do irmão dela. Aproveitando-se da posição de Maurice, eles acessam documentos confidenciais do cartório de Chantilly, descobrem segredos de seus moradores e passam a chantageá-los. Entre os prejudicados estão Clavier e Caroline Meilhan. A família de Clavier fora morta por nobres, parentes de Caroline. Durante a Revolução Francesa, Clavier aproveitou para vingar-se, matando toda a família, com exceção de Caroline, e apossando-se de seus bens. Arrependido, passa a cuidar da moça, ainda que não lhe devolva sua fortuna. Em um baile ela descobre que seu noivo tem um caso com Léonide, a mulher do notário. Desiludida, vai até uma estufa, onde acaba por morrer asfixiada. O outro traído, Maurice, fica desacreditado como profissional, pois se descobre que informações sigilosas foram divulgadas por sua própria mulher e seu cunhado. Além disso, fica em dificuldades financeiras quando um projeto de uma empresa de construção com o qual estava envolvido não se concretiza. Sua salvação vem justamente de um dos traidores. Seu cunhado, arrependido do que fizera, paga todas as dívidas de Maurice com a fortuna que ganhara ao apostar na volta da monarquia.

Picciola foi o grande sucesso de X.-B. Saintine. Dois anos após sua publicação em Paris, por Ambroise Dupont, o livro estava em sua oitava edição, já havia saído em Bruxelas e sido traduzido para o holandês. Dentre os romances aqui comentados, esse foi o único a ser publicado em português. Com tradução de Francisco Ladislau Alvares d'Andrada, estava na segunda edição em 1862 e ostentava no frontispício as informações: "obra premiada pelo Instituto de França" e "cotejada escrupulosamente com a trigésima-sexta do original e única approvada e consentida pelo autor"8. O romance narra a história do conde de Charney, um letrado ligado à ciência e à filosofia. Após ter sido descoberto como membro de uma sociedade que conspirava contra o governo de Bonaparte, é encarcerado como prisioneiro político. $\mathrm{Na}$ prisão, entedia-se desesperadamente com a impossibilidade de manter qualquer atividade. Com a chegada da primavera, maravilha-se com a descoberta de uma nova planta, que brotara no pátio e à qual dá o nome de Picciola. Gasta os dias a observá-la e analisá-la, encontrando alívio à ociosidade. Dessa maneira, começa a enxergar sua situação de maneira mais positiva e a interessar-se em conversar com o prisioneiro que ocupa a cela ao lado da sua. Assim, conhece

\footnotetext{
${ }^{7}$ Ver indicações das edições nas referências bibliográficas.

${ }^{8}$ Ver indicações das edições nas referências bibliográficas.

Jangada | nr. 16, jun/dez, 2020 | ISSN 2317-4722
} 


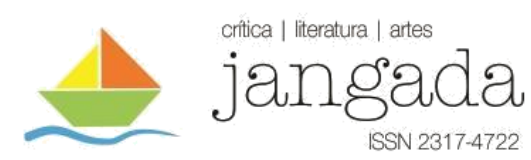

sua filha Teresa, por quem se apaixona. Ele é correspondido e passa a compartilhar a devoção à planta com a jovem. Ambos preparam uma carta, a ser entregue a Napoleão, solicitando a remoção de dois ladrilhos do pátio para dar mais espaço a Picciola. A autorização chega no exato momento em que o administrador da prisão dera a ordem para a liberação do prisioneiro. Além de salvar a planta, Teresa obtém o perdão para o namorado e casa-se com ele. Ela decide fazer transplantar Picciola para seu novo lar, causando involuntariamente sua morte.

Cronologicamente, o último romance analisado é Sathaniel, de Frédéric Soulié, publicado no final de 1836, por Ambroise Dupont, recebendo, nesse mesmo ano, edição em Bruxelas. O livro conheceu sucesso, com novas edições na capital da Bélgica e em Paris, além de ter sido traduzido para o alemão em 1838 e para o espanhol em 1843 e de ter recebido uma "nova edição, revista e corrigida", em Paris em 1841. ${ }^{9}$ A trama situa-se nos arredores da cidade de Toulouse, no século $\mathrm{V}$. Toda aquela região era dominada pelos visigodos cujo rei era Théodoric. Seu irmão, o príncipe Euric, deseja o trono para si e tem uma personalidade cheia de vícios, como a ambição e a luxúria. Disputas entre irmãos eram comuns, haja vista que o próprio Théodoric havia assassinado seu irmão mais velho, Thorismond, a fim de assumir seu reino. Apesar disso, ele é um rei justo, querido por seu povo e respeitado pelos mouros, seus vizinhos. Entre eles, está Sathaniel, a protagonista, uma mulher bela e sedutora, apaixonada pelo príncipe. Euric a seduz, mas não a desposa. O irmão da moça adverte o rei sobre o ocorrido e ele obriga o rapaz a cumprir seu dever. Entretanto, ele havia anunciado seu noivado com Alidah, de quem realmente gosta, o que decepciona Sathaniel e enfurece o rei. Ele exige que o príncipe e a moura se casem, o que é imediatamente feito. Após a união, Théodoric envia o irmão para uma batalha em Narbonne, na qual ele é feito prisioneiro. Depois de libertado, seus problemas continuam, pois Sathaniel, enciumada, acusa-o, perante o tribunal, de traí-la com Alidah. A denúncia é falsa, mas ela vence, tornando Alidah sua escrava. O príncipe, ainda que não consiga amar sua esposa, alia-se a ela, em sua estratégia para conquistar o trono, dando um bem-sucedido golpe. Quando se torna rei, Eric envia Sathaniel de volta à África e governa sem inimigos por muito tempo.

\section{AS CRÍTICAS}

Com exceção dos necrológios e dos perfis literários, a crítica costumava comentar livros recentemente lançados, o que auxiliava em sua divulgação somando-se aos anúncios e às notas

\footnotetext{
${ }^{9}$ Ver indicações das edições nas referências bibliográficas. Jangada | nr. 16, jun/dez, 2020 | ISSN 2317-4722 


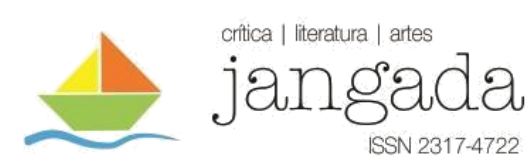

sobre o lançamento (MELMOUX-MONTAUBIN, 2003, p. 13). Assim foi em 1836, ano de publicação dos cinco romances que foram objeto de análise em ambos os jornais. Le Chemin de Traverse foi comentado no Le Constitutionnel por I.C.T. em 23 de junho e no La Presse por Fredéric Soulié em 05 de julho. Le Notaire de Chantilly foi analisado no Le Constitutionnel por I.C.T. em duas partes (Parte 1, 25 de agosto e Parte 2, 04 de setembro) e no La Presse por Fredéric Soulié, em 19 de setembro. Une Couronne d'Épines foi analisado no La Presse por Fredéric Soulié, em 19 de setembro (em texto em que comenta conjuntamente as obras de Gozlan e de Masson) e no Le Constitutionnel por I.C.T. em 23 de setembro. Picciola foi comentado no Le Constitutionnel por I.C.T. em 15 de novembro e no La Presse, por Fréderic Soulié, em 9 de janeiro de 1837. Finalmente, Sathaniel foi discutido no La Presse por Alphonse Rastoul, em 13 de dezembro e no Le Constitutionnel por I.C.T em 9 de dezembro de 1836.

Nenhuma das críticas a esses romances é completamente negativa, ainda que haja restrições aqui e ali. No geral, as avaliações publicadas no Le Constitutionnel são mais duras do que as do La Presse e poderiam ser consideradas apenas moderadamente positivas. Soulié, em seus comentários no La Presse, faz poucas ressalvas às obras e as avalia de maneira bastante favorável, da mesma forma que só recebeu elogios de Rastoul em sua crítica a Sathaniel. Mesmo que, eventualmente, não cheguem a uma mesma apreciação, os três críticos adotam procedimentos semelhantes nas avaliações e escrevem de maneira parecida.

Eles empregam uma estratégia textual comum: iniciar o texto com comentários gerais sobre temas diversos (que poderiam ir da política à religião, da literatura aos costumes) e associar a eles um traço qualquer da narrativa em avaliação. Em seguida, discutem elementos internos à obra e concluem com uma recomendação ou com felicitações.

O comentário geral com que costumam abrir seus textos pode ocupar um espaço considerável, tendo por função contextualizar o livro em apreço ou simplesmente permitir que o crítico trate livremente sobre um assunto de seu interesse sem a preocupação de se debruçar sobre o romance. Assim, o texto sobre Picciola principia com um comentário sobre o gênero romanesco, intitulado "Du Roman", em que Soulié discorre sobre como ele era visto naquele momento pela crítica francesa: apesar de ser olhado com desprezo, ele ofereceria as melhores obras, com destaque para os trabalhos de Chateaubriand, Alexandre Dumas, Victor Hugo, Honoré de Balzac, George Sand e Eugène Sue. Esses autores seriam especiais, pois, além de fenômenos de popularidade, apresentariam uma qualidade literária superior em seus romances, superando obras de história, de poesia e de teatro. Soulié, ele próprio um romancista, afirma 


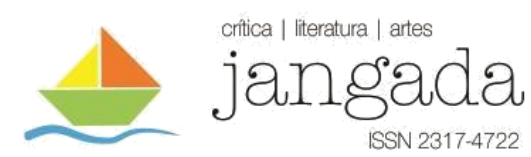

categoricamente: "o romance é a verdadeira literatura da época"10, e passa a comentar a narrativa, objeto de sua análise.

Outro exemplo nesse sentido é a crítica de Adolph Rastoul sobre Sathaniel, que principia com uma reflexão sobre a vida na Grécia Antiga e sua relação com o tardio surgimento do gênero romanesco para concluir com uma fórmula, muito difundida nos séculos XVIII e XIX, segundo a qual "hoje, o romance é para nós o que o épico já foi no passado". ${ }^{11}$ Como marco desse novo gênero, destaca Walter Scott e seus romances históricos, de quem Soulié e seu Sathaniel seriam herdeiros. Em defesa do gênero, Rastoul afirma que "a velha crítica, aquela crítica estreita e mesquinha que conta os defeitos e negligencia as belezas" teve de render-se às obras do escocês. Essa "velha crítica" sustentava, no entanto, "tinha privilégio exclusivo de inspirar tais composições", o que foi desmentido por Soulié, que "aceitou o desafio e se encarregou de responder em nome do Languedoc"12 (RASTOUL, 1836, p. 3), concebendo seu romance ambientado no século $\mathrm{V}$.

No caso das críticas publicadas em Le Constitutionnel, essa introdução costuma ser seguida pela apresentação dos enredos, que podia ser feita de maneira bastante detalhada, ocupando, em alguns casos, parte substancial do espaço disponível. Em todos os seus textos, I.C.T. apresenta um minucioso resumo, revelando até mesmo o destino final de personagens principais. Já em La Presse, seja nas críticas assinadas por Soulié, seja na de Rastoul, não há resumos do enredo, concatenando-se a introdução diretamente a algum elemento do texto, como a construção das personagens ou o estilo do autor.

Apresentando ou não resumo, um aspecto do enredo é frequentemente considerado, a moralidade da narrativa, uma preocupação não apenas dos críticos, mas dos próprios autores, que a colocavam no cerne de suas histórias. Assim é no caso de Le Chemin de Traverse, por exemplo. I.C.T., após detalhada apresentação do enredo, elogia a caracterização de Christophe, o irmão trabalhador, e de Prosper, o ambicioso, bem como a conclusão "moral e consoladora"13 da narrativa, pois o virtuoso foi recompensado, e o pecador, castigado. Isso daria um bom exemplo aos leitores, tendo em vista que "o anjo derrota o demônio, como sempre deveria

\footnotetext{
10 "le roman est la vraie littérature de l'époque" (SOULIÉ, 1837, p. 1).

11 “Aujourd'hui, le roman est pour nous ce qu'était jadis l'épopée" (RASTOUL, 1836, p. 3)

12 "La vieille critique, cette critique étroite et mesquine qui compte les défauts et néglige les beautés, en revint à ses premiers errements; elle ne pouvait nier Walter Scott. (...) Seulement, la critique persistait à soutenir que l'Ecosse avait le privilège exclusif d'inspirer de semblables compositions. M. Frédéric Soulié a relevé le gant; il s'est chargé de répondre au nom du Languedoc." (RASTOUL, 1836, p. 3)

13 "morale et consolante"(I.C.T., 1836a, p.1).
} 
ser" ${ }^{14}$, ao contrário do que ele vê como tendência na literatura daquele momento, na qual personagens como Don Juan e "outros maus sujeitos desse tipo"15 eram glorificados.

Da mesma forma, Soulié deixou clara a importância da moralidade em sua crítica a Une Couronne d'Épines e a Le Notaire de Chantilly, afirmando que "todas as qualidades e todos os defeitos desses livros [são] consequência direta dos seus princípios". ${ }^{16}$ As duas obras, assim como Le Chemin de Traverse e Sathaniel, têm enredos que permitem esse tipo de comentário, visto que opõem bons e maus indivíduos e terminam com a punição dos viciosos e a recompensa dos virtuosos. No entanto, nem toda caracterização moral era bem aceita. Soulié avalia que a atuação da personagem Prosper e a exploração de sua esposa para subir na sociedade era uma ideia ultrapassada e mal executada: "é errado, é falso, é embaraçoso, é frio", ${ }^{17}$ e recomenda que essas passagens sejam refeitas.

Sugerir alterações em uma obra já publicada poderia parecer descabido, mas não é, já que os autores podiam fazer importantes modificações entre as edições. Janin já havia modificado seu romance da primeira para a segunda edição, corrigido erros graves como divergências "de data, de nome, de fisionomia, que fizeram seus heróis mais jovens ao fim do livro do que eram em seu começo; que lhes deram um nome e depois outro, e fizeram-lhes loiros de morenos que tinham sido"18. Em sua crítica, Soulié explicitou esses problemas, mas considerou-os "pequenos anacronismos"19, "pequenas manchas" 20 , enaltecendo o fato de eles terem sido corrigidos na segunda edição, sem deixar de comentar que eles "tinham dado uma grande alegria aos inimigos do autor" ${ }^{21}$. Os equívocos de Janin foram também mencionados na crítica do Le Constitutionnel, sem que fossem especificados, indicando que a nova edição, saída à luz no mesmo dia da publicação da crítica, teria sanado todos os defeitos. Embora não tenha elencado uma lista de erros, I.C.T. foi mais severo que Soulié, considerando que o romance tinha sido "um trabalho precipitado e de uma evidente negligência". ${ }^{22}$ Apesar de repreender o autor, o crítico elogia sua capacidade de corrigir e melhorar suas obras em suas reedições: "ao

\footnotetext{
14 “l'ange écrase le démon, comme cela se doit”(I.C.T., 1836a, p.1)

15 “autres mauvais sujets de ce genre"(I.C.T., 1836a, p.1)

16 “toutes les qualités et tous les défauts de ces livres sont l'inévitable conséquence de ces principes." (SOULIÉ, $1836 \mathrm{~b}, \mathrm{p} .4)$

17 "C'est faux, c'est embarrassant, c'est froid.” (SOULIÉ, 1836b, p.4)

18 "de date, de nom, de physionomie, qui faisaient ses héros plus jeunes à la fin du livre qu'ils ne l'étaient au commencement; qui leur donnaient tantôt un nom tantôt un autre, et les faisaient blonds de bruns qu'ils avaient été." (SOULIÉ, 1836a, p.1)

19 “petits anachronismes"(SOULIÉ, 1836a, p.1)

20 "petites taches".(SOULIÉ, 1836a, p.1)

21 "avaient donné une trop grande joie aux ennemis de Janin". (SOULIÉ, 1836a, p.1)

22 "travail hâtif, et de négligence flagrante." (I.C.T., 1836a, p. 1)
}

Jangada | nr. 16, jun/dez, 2020 | ISSN 2317-4722 
invés de se imobilizar ao observar suas falhas, ele trabalha para conhecê-las, compreendê-las, corrigi-las"23.

A crítica de Soulié à obra de Janin é singular no conjunto observado, pois, apesar de comentá-la, ele se concentra, sobretudo, na figura do escritor, que ganha destaque até mesmo na formatação do título, que traz, em primeiro lugar e com corpo maior, o nome do autor e, embaixo e com fonte menor, o nome da obra. Admitindo sem reservas seu envolvimento pessoal, Soulié declara: "há vários anos que Jules Janin é nosso camarada: ele, eu e muitos outros começamos juntos nossa carreira literária". ${ }^{24}$ E ocupa praticamente todo o espaço do folhetim com considerações sobre o escritor, entre as quais uma longa apresentação de uma viagem que ambos fizeram com um grupo de amigos a Chantilly. Apesar da banalidade do passeio, Soulié lança mão do episódio para caracterizar Janin como alguém especial. Ao contrário de seus amigos mais extrovertidos, ele vagava pelos bosques, dedicando-se à meditação e à poesia. Tinha mudanças bruscas de humor e uma tendência a comportamentos agressivos. Seu modo de agir, aliado ao amplo conhecimento de autores teatrais clássicos, explicaria seu grau de exigência e a agressividade presente em suas avaliações de gêneros teatrais menores como as óperas cômicas e os vaudevilles. Perdoava-o, assim, por suas avaliações mais rígidas, impostas por seu gênio superior. A obra é comentada apenas na última parte da crítica, mas a atenção logo se volta novamente para o autor, dessa vez por sua forma de escrever. O crítico define o estilo como "uma forma particular, pessoal, que marca cada uma das frases de um escritor com algo próprio e que faz ser reconhecido entre mil”. Para ele, Janin é "aquele que entre todos nossos escritores cuja individualidade é o mais completa e constantemente à mostra." 25 . Ele seria uma referência no gênero: "Janin fez escola, seu estilo foi copiado por muitos medíocres que não o reconheciam e ele se impôs sobre escritores renomados que fingem desprezá-1o"26. Ainda assim, considera seu estilo monótono por não haver em suas obras variações entre os tons sério e cômico, o que seria desejável. Leve admoestação, logo ofuscada pelas previsões auspiciosas com que conclui o texto: sua posição futura no meio literário "pode superar todas as esperanças que ele nutre"27.

\footnotetext{
23 "qu'au lieu de s'immobiliser dans l'admiration de ses défauts, il travaille à les connaître, à les saisir, à s'en corriger." (I.C.T., 1836a, p. 1)

24 "Il y a bien des années que Jules Janin est notre camarade: lui, moi et beaucoup d'autres, nous avons commencé ensemble notre carrière littéraire.” (SOULIÉ, 1836a, p. 1)

25 "nous entendons par style une forme particulière, personnelle, qui marque chaque phrase d'un écrivain d'un coin qui lui est propre, et qui la fait reconnaître entre mille; et, s'il faut le dire, Janin est, à notre avis, celui de tous nos écrivains dont l'individualité est le plus complètement et le plus constamment en relief." (SOULIÉ, 1836a, p. 1) 26 "Janin a fait école, son style a été copié par beaucoup de médiocrités qui le méconnaissent, et il s'est imposé à des écrivains renommés qui affectent de le mépriser." (SOULIÉ, 1836a, p. 1)

27 "peut-être au-dessus des espérances qu'il nourrit" (SOULIÉ, 1836a, p. 1)
}

Jangada | nr. 16, jun/dez, 2020 | ISSN 2317-4722 


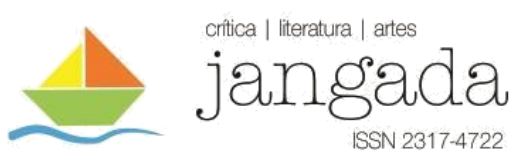

A posição de destaque ocupada por Janin naquele momento, especialmente no $L a$ Presse, pode ser percebida também pelo fato de ele ter voltado à cena na crítica elaborada por Soulié ao romance Le Notaire de Chantilly. O crítico examina as virtudes e os defeitos do romance de Gozlan a partir da obra Le Chemin de Traverse, que retorna, assim, às páginas do jornal menos de três meses depois da longa crítica anterior. Ele destaca o fato de Gozlan ter colaborado com o jornal Figaro junto com Janin e atribui a essa convivência "esse desprezo pelo mundo" ${ }^{28}$, visível nos dois romances. O estilo de Gozlan, no entanto, teria vantagens, pois ele produziria "frases não menos cintilantes do que as mais belas frases do Sr. Janin", mas seria "mais senhor de seu pensamento e de sua pena do que o engenhoso escritor do Journal des Débats" ${ }^{29}$. As comparações prosseguem, sempre com vantagem para Gozlan, resultando em crítica mais acerba ao romance de Janin do que a realizada no texto especialmente dedicado a Le Chemin de Traverse. Segundo Soulié, as personagens de Le Notaire são mais bem construídas: "como os personagens do Sr. Janin, os seus são cheios de paradoxos e de opiniões altamente questionáveis; mas ao contrário do Sr. Janin, que arremessa todas as suas ideias desconexas na boca do primeiro de seus heróis, o Sr. Gozlan preserva em cada um deles o paradoxo com o qual constituiu seu caráter"30. Não há desvios no decoro entre fala e condição como em Janin, em cujo romance "se fala a mesma língua indiferentemente através das vozes de velhos e jovens, homens e mulheres”. E não há problemas de consistência interna, como há na obra de Janin, que "insere suas confusas opiniões em todos os lugares, de modo que todos os seus atores têm uma semelhança geral", ao mesmo tempo em que "ele os embeleza com a inconsistência de seus próprios pontos de vista e os faz mentir para si mesmos", de modo que, no final do livro, "eles não se pareçam com o que eram no início." 31 . Todos esses defeitos são atribuídos ao fato de Janin "render-se aos direitos que seu talento adquiriu, de ser ilógico, esquecido e substituir a nitidez do desenho pela riqueza constante da mesma cor" 32 . Ao

\footnotetext{
28 "ce mépris pour le monde" (SOULIÉ, 1836b, p. 4)

29 "des phrases qui ne papillotent pas moins aux yeux que les plus belles phrases de M. Janin, seulement M. Gozlan est plus maître de sa pensée et de sa plume que l'ingénieux écrivain" (SOULIÉ, 1836b, p. 4)

30 "Comme les personnages de M. Janin, ses personnages sont pleins de paradoxes et d'opinions fort contestables; mais au contraire de M. Janin, qui jette pêle-mêle tout ce qu'il a d'idées décousues, dans la bouche du premier venu de ses héros, M. Gozlan conserve à chacun de ses personnages le paradoxe dont il lui a fait un caractère"(SOULIÉ, 1836b, p. 4)

31 "M. Janin parle indifféremment le même langage par la voix des vieux et des jeunes, des hommes et des femmes, tandis qu'il met partout la confusion de ses opinions, de manière que tous ses acteurs ont une similitude générale, et qu'en même temps il les affuble de l'inconséquence de ses propres vues et les fait se mentir à eux-mêmes, de manière encore qu'à la fin du livre ils ne ressemblent pas à ce qu'ils étaient au commencement." (SOULIÉ, 1836b, p. 4)

32 "M. Janin s'abandonne aux droits que son talent lui a acquis, d'être illogique oublieux et de remplacer la netteté du dessin par la richesse constante d'une même couleur." (SOULIÉ, 1836b, p. 4)
}

Jangada | nr. 16, jun/dez, 2020 | ISSN 2317-4722 176 |P á g i n a 
contrário, Gozlan "distingue bem os indivíduos, não confunde os tons de seus personagens e nunca deixa o leitor em dúvida sobre o que quis dizer e o que queria pintar" ${ }^{\prime 3}$. Ou seja, a comparação entre a produção de um amigo e escritor de destaque com a de um autor de menor prestígio favoreceu esse último, contrariando a ideia de que as relações de amizade e a consagração afetariam de maneira definitiva o julgamento.

Em sua crítica, Soulié também comenta Une Couronne d'Épine, cujo enredo tem evidentes semelhanças com Le Chemin de Traverse, o que poderia tê-lo levado a incluir o livro de Masson nas comparações que tece. Entretanto, não foram as semelhanças de enredo que chamaram sua atenção e sim as divergências de estilo e de construção de personagem.

Nos comentários publicados em Le Constitutionnel, as obras de Gozlan e de Masson são abordadas separadamente, cabendo a Le Notaire de Chantilly dois textos críticos e a Une Couronne d'Épine um outro. O primeiro deles possui uma estrutura incomum, pois é ocupado quase integralmente pela transcrição de uma passagem do romance, intitulada pelo crítico como "Morte de Caroline de Meilhan", na qual a moça se fecha em uma estufa de plantas e acaba morrendo asfixiada devido aos odores liberados pela vegetação (I. C. T., 1836b, p. 1). Embora ele tenha caracterizado as circunstâncias de uma tal morte como "um pouco estranhas", 34 justificou a longa citação afirmando que o trecho demonstra o talento de Gozlan na criação de descrições poéticas. Sabendo que a verossimilhança era um atributo esperado, comenta que mortes desse tipo eram "fisicamente possíveis" 35 , elogiando o autor, pois "não se afastou do círculo da realidade", ${ }^{36}$ mesmo quando estava "na esfera da mais doce poesia". ${ }^{37}$

Essa extensa citação pode ter tido por propósito dar a perceber a elegância do estilo do autor, como afirma o crítico, mas pode ter sido também uma hábil maneira de ocupar o espaço e resolver um eventual problema de tempo na elaboração da crítica, já que onze dias depois foi publicado um segundo comentário, dessa vez, com análise detalhada. Uma observação de Soulié, em uma de suas críticas, vai nesse sentido. Ele defende um prazo maior para julgar os romances, pois a rapidez na elaboração das críticas gerava uma análise "fria, incompleta e muitas vezes desajeitada" 38 . Entretanto, o fato de contar com duas publicações e, portanto, com

\footnotetext{
33 “M. Gozlan au contraire sépare bien les individus, ne confond point les teintes de leur caractère et ne laisse jamais le lecteur en doute de ce qu'il a voulu dire et de ce qu'il a voulu peindre." (SOULIÉ, 1836b, p. 4)

34 “quoiqu'étranges"(I. C. T., 1836b, p. 1)

35 "physiquement possibles" (I. C. T., 1836b, p. 1)

36 "ne s'est point écarté du cercle de la réalité." (I. C. T., 1836b, p. 1)

37 "la sphère de la plus douce poésie" (I. C. T., 1836b, p. 1)

38 "d'une analyse froide, incomplète, et trop souvent maladroite" (SOULIÉ, 1836b, p. 4)
}

Jangada | nr. 16, jun/dez, 2020 | ISSN 2317-4722

$177 \mid$ P á g i n a 
mais tempo e espaço, não fez com que a avaliação de I.C.T. diferisse muito da realizada por Soulié, que dedicou um único texto aos dois romances.

Ambos comentam o estilo de Gozlan, caracterizado por Soulié como "precioso, hábil, elegante (...), a frase cintila de hábeis figuras, de termos felizes, de antíteses brilhantes". ${ }^{39}$ A mesma ideia de brilho é utilizada pelo crítico do Le Constitutionnel, que afirma jamais ter visto "tantos brilhantes recursos de estilo". ${ }^{40}$ No entanto, os dois apresentam reservas quanto ao seu excesso. Soulié considera que os leitores, inclusive ele mesmo, ficam cansados de "acompanhar a caminhada com pequenos passos e pequenas frases do Sr. Gozlan", ${ }^{41}$ em seu ritmo pouco fluente, enquanto I.C.T faz uma única reserva - ainda que ele a considere "uma gloriosa reprimenda" 42 - ao considerar que o romance era "escrito excessivamente" ${ }^{43}$. O estilo também é um elemento de destaque na avaliação do romance de Michel Masson. Os dois críticos recriminam o excesso de detalhes e o tamanho dos períodos. Para Soulié, as "páginas inteiras em longos encadeamentos intermináveis" ${ }^{44}$ cansariam os leitores. Já I.C.T. foi menos rigoroso, destacando o progresso do autor em relação a obras anteriores e prevendo que "no próximo romance, teremos algo ainda melhor" 45 - o que indica que o resultado ainda não havia sido completamente positivo.

As avaliações de Picciola publicadas nos dois jornais também destacam a questão do estilo, com Soulié fazendo comentário inteiramente positivo, ainda que breve, e I.C.T. apresentando ressalvas e uma análise mais minuciosa. O crítico do Le Constitutionnel acredita que construções detalhadas podem afetar a leitura, tornando-a penosa. Ao mesmo tempo, rechaça o pouco aprofundamento que seria notável na literatura daquele momento, em nova nota depreciativa à produção literária de seu tempo. Para ele, é essencial manter um equilíbrio entre o estilo bem elaborado e um bom ritmo da leitura (I. C. T., 1836e, p. 1). Soulié também manifesta preocupação com as reações dos leitores - o que não aparece em nenhuma das outras críticas analisadas. Para ele, a história provoca fortes emoções - "Estas são as lágrimas que a história de Picciola arranca de vós" ${ }^{46}$ - e produz efeitos sobre os leitores - "Portanto, lede

\footnotetext{
39 "précieux, habile, élégant (...) la phrase étincelle d'ingénieuses figures, de termes heureux , d'antithèses scintillantes" (SOULIÉ, 1836b, p. 4)

40 "jamais tant d'éclatantes ressources de style" (I. C. T., 1836c, p. 1)

41 “accompagner la marche à petits pas et à petites phrases de M. Gozlan” (SOULIÉ, 1836b, p. 4)

42 "un glorieux reproche" (I. C. T., 1836c, p. 1)

43 "trop écrit" (I. C. T., 1836c, p. 1)

44 "pages entières en longues enjambées interminables" (SOULIÉ, 1836b, p. 4)

45 "Au prochain roman nous aurons mieux encore" (I. C. T., 1836c, p. 1)

46 "il a laissé tomber sur une de ses pétales quelques gouttes de douce rosée. Ce sont les larmes que vous arrache l'histoire de Picciola" (SOULIÉ, 1837, p. 1)
} 


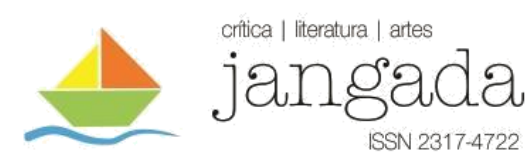

Picciola e que Deus perdoe aqueles que não sentirem no coração um doce bem-estar depois de ler esse livro, são os que não possuem nem alma nem coração."47

Outro elemento recorrente nas críticas é a avaliação da construção das personagens. I.C.T, por exemplo, ao comentar Le Notaire de Chantilly, destaca o comerciante David, especialmente elogiado, pois simbolizaria "o povo trabalhador em toda sua bondade", 48 contrapondo-se à nobreza e a sua devassidão moral. Enquanto isso, os plebeus David, Jane Pretty e Madame Fraser são considerados os três personagens "mais bem definidos"49 do romance. Os nobres não o agradam, por serem muito exagerados e representantes da "vulgaridade das virtudes", ${ }^{50}$ algo extremamente indesejado do ponto de vista moral. Ainda assim, haveria uma justificativa para tais excessos, pois eles gerariam um "efeito de contraste" 51 em relação aos personagens pobres e virtuosos. Do mesmo modo, I.C.T. destaca a constituição dos personagens em Sathaniel, em que haveria "uma justeza, uma graça e uma harmonia de cores", ${ }^{2}$ avaliação com a qual concorda Rastoul, que os elogia no La Presse, considerando que são "passionais" e "com contrastes habilmente construídos"

A avaliação de Sathaniel é a única em que a fidelidade ao real é destacada. Tratando-se de romance histórico, ambos os críticos se preocupam em verificar a correspondência com os acontecimentos. Assim, I. C. T. abre seu texto com uma longa explanação sobre os visigodos e o reinado de Teodorico I na França a fim de, segundo ele, "fazer nossos leitores compreenderem completamente a obra do Sr. Soulié." ${ }^{54}$ Embora reclame do fato de haver erro de datação das batalhas de Teodorico I, não espera que o autor se atenha exclusivamente ao registro histórico, elogiando a ficcionalização de personagens, como o monarca e sua família, assim como a invenção dos personagens árabes. Da mesma forma, Rastoul elogia o retrato dos povos árabes e visigodos, bem como o equilíbrio entre elementos históricos e fictícios, que inserem "mistério" na narrativa, o que seria "um dos maiores charmes da vida, duplicando nossos prazeres intelectuais" $" 55$.

\footnotetext{
47 "Lisez donc Picciola, et que Dieu pardonne à ceux qui ne se sentiront pas au coeur et à l'ésprit un doux bien aise après avoir lu ce livre, c'est qu'ils n'auront ni esprit ni coeur." (SOULIÉ, 1837, p. 1)

48 "le peuple ouvrier dans toute sa bonté" (I. C. T., 1836c, p. 1)

49 "mieux accusées" (I. C. T., 1836c, p. 1)

50 "vulgarité des vertus" (I. C. T., 1836c, p. 1)

51 "comme effet de repoussoir" (I. C. T., 1836c, p. 1)

52 "une justesse, une grâce et une harmonie de couleur" (I.C.T., 1836f, p. 1)

53 "passionnés", "contrastes habilement ménages" (RASTOUL, 1836, p. 1)

54 "initier nos lecteurs à l'intelligence complète du livre de M. Frédéric Soulié" (I.C.T., 1836f, p. 1)

55 "le mystère est un des plus grands charmes de la vie, il double nos jouissances intellectuelles." (RASTOUL, 1836, p. 1)
}

Jangada | nr. 16, jun/dez, 2020 | ISSN 2317-4722 
As considerações finais dos críticos também guardam semelhanças. Elas são escritas em tom bastante positivo, mesmo nos casos em que falhas haviam sido apontadas. Soulié, por exemplo, tendo feito variadas considerações negativas sobre as obras de Gozlan e de Masson, conclui seu texto vaticinando que elas seriam populares durante um longo tempo: "um [Une Couronne d'Épines] viverá pela boa ordem e a perfeição do conjunto, o outro [Le Notaire de Chantilly] pela superioridade dos detalhes." ${ }^{~} 56$ A permanência das obras também é citada por I.C.T. em sua análise de Le Notaire de Chantilly, o que parece indicar que esse elogio era mais um dos lugares-comuns aos quais os avaliadores recorriam, mesmo quando apontavam defeitos nos escritos. A partir dessa publicação, Gozlan estaria entre os "principais romancistas, com vontade e talento necessários para agir sobre a sociedade, com o objetivo de uma influência útil e moral".57 Já Une Couronne d'Épines é chamado por Soulié de "o melhor livro da escola instituída por Richardson", 58 porém a crítica é concluída com recomendações a Masson sobre o aprimoramento de seu estilo: "o vigor na estrutura, não exclui (...) o charme do colorido e elegância na forma"59. Da mesma maneira, I.C.T. termina a avaliação de Picciola dando conselhos a Saintine, que deveria fazer "o sacrifício de algumas evocações um pouco banais", e evitar "paradoxos mais bonitos do que verdadeiros"60. Para não fechar a avaliação em tom negativo, conclui dizendo que tais solicitações se justificam, pois "a obra nos pareceu tão bonita que nos fez desejar vê-la perfeita" ${ }^{\prime}$.

Vê-se que Soulié, I.C.T. e Rastoul tinham ideias bastante parecidas sobre romances, sobre o papel de suas avaliações e sobre o modo de escrevê-las.

Para eles, os romancistas deveriam cuidar do estilo, mas não era recomendável que isso atrapalhasse o andamento do enredo (que parece ser a prioridade) nem tornasse a leitura cansativa. Era necessário construir situações em que houvesse uma tensão moral e que as personagens se alinhassem entre os polos da virtude e do vício. Com menos intensidade, preocupavam-se com a verossimilhança e, no caso do romance histórico, com a correspondência com os fatos. Nenhuma atenção foi dada à construção de cenários, ao trabalho com o tempo, ou ao modo de ser dos narradores. Essa visão coincide com a de outros letrados

\footnotetext{
56 "L'un vivra par le bon ordre et la perfection de l'ensemble, l'autre par la supériorité des détails." (SOULIÉ, $1836 \mathrm{~b}, \mathrm{p} .4)$

57 "premiers romanciers, avec la volonté et le talent nécessaires pour agir sur la société , dans un but d'influence utile et morale." (I.C.T., 1836c, p. 1)

58 "le meilleur livre de l'école instituée par Richardson." (SOULIÉ, 1836b, p. 4)

59 "la vigueur de la charpente n'exclut pas (...) le charme du coloris et l'élégance de la forme" (SOULIÉ, 1836b, p. 4)

60 "le sacrifice de quelques évocations un peu communes, (...) paradoxes plus jolis que vrais" (I.C.T., 1836e, p. 1)

61 "l'œuvre nous a paru assez belle pour nous faire désirer de la voir parfaite"(I.C.T., 1836e, p. 1)
}

Jangada | nr. 16, jun/dez, 2020 | ISSN 2317-4722 $\quad 180$ |P á g i n a 


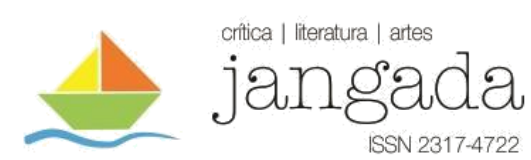

em avaliações de romances produzidas desde o final do século anterior, revelando a existência de referências e repertórios partilhados (ABREU, 2016; ABREU, MITTMANN, 2017a, 2017b). A diferença no espaço destinado a cada um dos comentários (com alguns se desdobrando em dois números e outros aglutinando dois romances em um único texto) não gerou mudanças significativas nos critérios de avaliação, o que permite perceber que eles eram considerados essenciais, fazendo com que o tamanho das críticas apenas tornasse as análises menos ou mais detalhadas.

Para eles, dentre as finalidades das críticas estava a de apontar defeitos e acertos nos livros, os quais deveriam servir como referência para os escritores em suas próximas criações ou, até mesmo, na reelaboração de narrativas já publicadas, parecendo supor que os autores os leriam e, eventualmente, seguiriam seus conselhos. Elas também tinham por objetivo dar a conhecer a obra, mas esse não era o elemento de maior destaque, já que publicações de sucesso esgotavam edições antes mesmo que os críticos pudessem comentá-las, como ocorreu com ambos os textos sobre Le Chemin de Traverse que principiam com a afirmação de que "todo o mundo o leu"62 e que pouco há a dizer por ele "já ter sido lido em toda parte"63.

Os críticos parecem acreditar, ainda, que o bom modo de construir seus textos é partir de considerações sobre questões mais amplas com as quais o romance tivesse alguma relação, sem focar exclusivamente nas obras, e concluí-los com uma nota positiva.

\section{CONCLUSÃO}

A análise dos textos críticos indicou que há fortes semelhanças entre eles e seus autores. Os pontos de contato são muitos: pertenciam à mesma geração, viviam em Paris (à exceção de Rastoul) e, além de críticos, eram autores com obra publicada. Tendo aproximadamente a mesma idade, devem ter tido formação escolar similar e, possivelmente, lido muita coisa em comum. Provavelmente, liam-se uns aos outros. Tudo isso os levou a avaliar os romances e a escrever seus textos de modo análogo, ainda que seus gostos pessoais os levassem a apreciar ou rejeitar certas passagens e soluções estilísticas.

Assim, a diferença política entre os dois jornais não afetou os elementos a serem avaliados nem a forma de fazê-lo (GABRIELLI, 2018). O público dos periódicos também não parece ter produzido impacto. La Presse era destinado a leitores mais populares, que poderiam

\footnotetext{
62 "tout le monde a lu" (SOULIÉ, 1836a, p. 1)

63 "d'un livre déjà lu partout" (I. C. T., 1836a, p. 1)
}

Jangada | nr. 16, jun/dez, 2020 | ISSN 2317-4722 


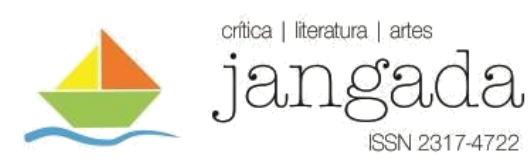

gostar de ler resumos de histórias, mas Soulié não faz sínteses de enredo e dedica suas críticas ao comentário de elementos internos aos textos. Le Constitutionnel, menos popular, ocupa parte importante do espaço destinado à crítica sumariando as narrativas. De um jornal mais elitizado seriam esperadas críticas mais duras, tendo em vista a rejeição das camadas eruditas aos romances, mas isso não aconteceu. Opiniões rígidas também poderiam ser favorecidas pelo fato de o crítico de Le Constitutionnel assinar seus textos com pseudônimo. Isso tampouco ocorreu. Os resultados foram predominantemente positivos nos dois jornais, pois, apesar de fazerem comentários depreciativos sobre vários aspectos, eles eram justificados em seguida ou contrabalançados com elogios a outros aspectos, suavizando o tom. Essa pode ter sido uma forma encontrada para avaliar as obras sem oporem-se frontalmente aos romancistas (que eram, eles também, atuantes na imprensa), nem aos editores e anunciantes dos jornais.

Esse parece ser um elemento mais relevante para a compreensão do funcionamento da crítica do que a orientação política dos jornais: autores, editores e críticos eram próximos. Em alguns casos, mantinham estreita relação, como ficou evidente no texto de Soulié sobre o romance de Janin, em que praticamente não se analisa a obra, deixando todo o espaço para a figura do escritor e sua amizade com o crítico. O editor Ambroise Dupont é também um elo que une o conjunto de autores cujos textos foram analisados: as obras de Janin, Masson, Soulié e Saintine foram todas publicadas por ele. A exceção é o romance de Gozlan, mas mesmo assim ele se mantinha no mesmo círculo, pois Dupont havia sido o responsável pela publicação, em 1828, de seu livro Le Triomphe des Omnibus (AUDEBRAND, 1970, p. 8). Os romancistas mantiveram-se juntos em outros empreendimentos editoriais como a coletânea Les mille et un romans, nouvelles et feuilletons, em que foram publicados, no mesmo volume, um romance de Soulié, um de Gozlan e a reimpressão de Une Couronne d'Épines, de Masson.

$\mathrm{O}$ fato de quatro dos cinco romances comentados terem tido o mesmo editor poderia levar a supor que a publicação de textos críticos fosse uma ação editorial para divulgação dos livros. Se esse elemento não pode ser descartado, tampouco deve ser considerado com excessivo peso. Como se viu no caso do livro de Janin, os comentários foram feitos sobre edição corrigida, tendo em vista que a primeira tiragem já havia se esgotado muito antes de qualquer comentário na imprensa. Uma crítica positiva poderia ajudar a alavancar as vendas, mas elas não dependiam inteiramente disso.

A disposição de Janin de corrigir os notáveis erros que deixou passar na primeira edição de Le Chemin de Traverse foi exaltada por ambos os críticos como algo notável e digno de elogio. Isso pode indicar que a consagração do autor interferia na disposição dos comentadores, 
fazendo com que eles se tornassem dispostos a perdoar até mesmo os mais óbvios equívocos. Entretanto, essa mesma obra foi bastante criticada em um segundo momento, pelo mesmo crítico, que a contrapôs à produção de Gozlan, autor iniciante e de baixo reconhecimento. $\mathrm{O}$ cotejo entre o romance do principiante e o do grande autor resultou em elogio ao primeiro e desaprovação do segundo. Isso mostra que a crítica não era apenas elogiosa e que o peso da consagração, embora grande, não era absoluto.

As conclusões a que chegamos contrariam o que afirmavam alguns letrados da época e também alguns estudiosos de hoje, como Melmoux-Montaubin (2003). Para eles, a influência de interesses pessoais dos críticos e publicitários dos jornais era um impedimento para uma avaliação literariamente relevante e, por conseguinte, para a elaboração de pesquisas sobre a crítica produzida no início do século XIX. Este estudo permitiu um melhor entendimento sobre a recepção do gênero romanesco nesse período e mostrou que os textos avaliativos oriundos dos periódicos podem ser prolíficas fontes de investigação.

\section{REFERÊNCIAS BIBLIOGRÁFICAS}

ABREU, M. "Uma comunidade letrada transnacional: reação aos romances na Europa e no Brasil”. In: ABREU, M. (org.) Romances em movimento: a circulação transatlântica dos impressos (1789 -1914). Campinas / São Paulo: Editora da Unicamp / FAPESP, 2016.

ABREU, M., MITTMANN, A. Lendo milhares de páginas em um dia: uma análise digital de textos críticos produzidos entre os séculos XVIII e XIX. In: Leitura: teoria \& prática, v. 35, n. 71, p.31-48, 2017.

Ler o passado com ferramentas do futuro: uma análise digital de textos críticos do início do século XIX. In: Alea, v.19, no.3, p.651-667, dezembro de 2017.

AUDEBRAND, P. Léon Gozlan: scènes de la vie littéraire (1828-1865). Genève, Slatckine Reprints, 1970.

BARBIER, A. A. Dictionnaire des ouvrages anonymes, Troisième Édition, revue et augmentée par MM. Olivier Barbier, René et Paul Billard. Volume 1. Paris: Paul Daffis, Libraire-Éditeur, 1872, p. 733. Disponível em:

$<$ https://books.google.com.br/books?id=MfrDzQEACAAJ\&dq=Dictionnaire+des+ouvrages+ anonymes\&hl $=$ ptPT $\&$ sa $=X \& v e d=2$ ahUKEwiGzbOZ38vsAhV8H7kGHdxqCGwQ6AEwB3o ECAAQAQ>. Acesso em 20/10/20. 
BIRÉ, E. \& GRIMAUD, É. Les poètes lauréats de L'Académie française, 1671 - 1830, Volume 1. Paris: A. Bray, Libraire-Éditeur, 1865.

BRISSON, J.; RIBEYRE, F. Les grandes journaux de France. Paris: Impresseur Jouaust père et fils, 1862 .

CASANOVA, P. A República Mundial das Letras. São Paulo: Estação Liberdade, 2002.

CHAMPION, M. Frédéric Soulié, sa vie et ses ouvrages. Paris: Moquet, 1847, p. 14-31. Disponível em: <http://gallica.bnf.fr/ark:/12148/bpt6k5790734c>. Visitado em: 12/06/2017.

D.; RÉGNIER, P.; THÉRENTY, M.-È.; VAILLANT, A. La Civilisation du Journal : Histoire culturelle et littéraire de la presse française au XIX siècle. Paris: Nouvelle Monde, 2011.

FEYEL, G. "L'économie de la presse au XIX ${ }^{\mathrm{e}}$ siècle". In: KALIFA, D.; RÉGNIER, P.; THÉRENTY, M.-È.; VAILlANT, A. La Civilisation du Journal : Histoire culturelle et littéraire de la presse française au XIX siècle. Paris: Nouvelle Monde, 2011.

GABRIELLI, B. "Criticar já é distinguir”: a avaliação de romances em periódicos franceses do século XIX. 2018. 134 p. Dissertação de Mestrado - UNICAMP, Campinas (SP).

GLINOER, A. Classes de textes et littérature industrielle dans la première moitié du XIX ${ }^{\mathrm{e}}$ siècle. COnTEXTES (Online), 2009. Disponível em: 〈htttp://contextes.revues.org/4325>. (Acesso em: $26 / 10 / 20)$.

GOZLAN, L. Le Notaire de Chantilly. Bruxelles, Société Belge de Librairie, 1836. . Le Notaire de Chantilly. Bruxelles: J. P. Meline, 1836.

- Le Notaire de Chantilly. Bruxelles: J. Jamar, 1836. Disponível em <https://gallica.bnf.fr/ark:/12148/bpt6k9734544g.texteImage>. Acesso em 18/09/2020.

. Le Notaire de Chantilly. Paris: Librairie de Dumont, 1836.

. Le Notaire de Chantilly. Bruxelles, Ad Wahlen, 1836.

HUART, L. "Michel Masson”. In: HUART, L.; PHILIPON, C. Galerie de la presse, de la littérature et des beaux-arts. Paris: Aubert, 1840, s/p.

I. C. T. Le Chemin de Traverse. Le Constitutionnel, 23/06/1836.

Le Notaire de Chantilly, par M. L. Gozlan. Le Constitutionnel, 04/09/1836.

Le Notaire de Chantilly, par M. L. Gozlan. Le Constitutionnel, 25/08/1836.

Picciola. Pages de la Vie Intime. Le Constitutionnel, 15/11/1836.

- Sathaniel, Romans historiques du Languedoc, par M. Frédéric Soulié. Le Constitutionnel, 09/12/1836.

. Une Couronne d'Épines. Le Constitutionnel, 23/09/1836. 
JANIN, J. Le Chemin de Traverse. Quatrième édition entierement revue et corrigée. Paris: Ambroise Dupont, 1836. Disponível em:

$<$ https://books.google.com.br/books?id=4LYUAAAAQAAJ\&printsec=frontcover\&hl=ptBR\&source=gbs_ge_summary_r\&cad=0\#v=onepage\&q\&f=false >. Acesso em 18/09/20. JOUKOVSKY, F. Jules Janin et son temps. Paris: Presses Universitaires de France, 1974. KALIFA, D.; RÉGNIER, P.; THÉRENTY, M.-È.; VAILLANT, A. "Les scansions internes à l'histoire de la presse". In: KALIFA, D.; RÉGNIER, P.; THÉRENTY, M.-È.; VAILLANT, A. La Civilisation du Journal: Histoire culturelle et littéraire de la presse française au XIX siècle. Paris: Nouvelle Monde, 2011.

LATOUCHE, H. de. De la camaraderie littéraire. Revue de Paris, Paris, tomo VII, p. 104-110, outubro de 1829.

Le Constitutionnel, 02/05/1836, p. 1.

LIESEN, B. Biliothèques populaires et bibliothèques publiques en Belgique (18601914): l'action de la Ligue de l'enseignement et le réseau de la Ville de Bruxelles. Liège, Éditions du CEFAL, 1990.

LYON-CAEN, J. "Lecteurs et lectures: les usages de la presse au XIX ${ }^{\mathrm{e}}$ siècle". In: KALIFA, D.; RÉGNIER, P.; THÉRENTY, M.-È.; VAILLANT, A. La Civilisation du Journal : Histoire culturelle et littéraire de la presse française au XIXe siècle. Paris: Nouvelle Monde, 2011.

MASSON, M. Une Couronne d'épines. Bruxelles: J. Jamar, 1836.

. Une Couronne d'épines. Bruxelles: Meline, 1836. . Une Couronne d'épines. Bruxelles: Wahlen, 1836. . Une Couronne d'épines. Bruxelles: Allgemeine niederlandische Buchhandlung, 1836.

. Une Couronne d'épines. Paris, Ambroise Dupont, 1836, $3^{\mathrm{a}}$ edição. Disponível em <https://books.google.com.br/books?id=LgM6AAAAcAAJ\&printsec=frontcover\&hl=ptBR\&source=gbs_ge_summary_r\&cad=0\#v=onepage\&q\&f=false $>$. Acesso em 18/09/2020. MELMOUX-MONTAUBIN, M.-F. "La critique littéraire”. In: KALIFA, D.; RÉGNIER, P.; THÉRENTY, M.-̇̀.; VAILLANT, A. La Civilisation du Journal: Histoire culturelle et littéraire de la presse française au XIX ${ }^{e}$ siècle. Paris: Nouvelle Monde, 2011.

Autopsie d'un décès. La critique dans la presse quotidienne de 1836 à 1891 . Romantisme, v. 3, n 121 , p. 9-22, 2003.

Paris: Au Bureau de la Revue, 1850. Disponível em: 
$<$ https://books.google.com.br/books?id=HD79VODHse4C\&pg=PA8\#v=onepage\&q\&f=false >. Acesso em 20/10/20.

RASTOUL, A. Léopold I ${ }^{e r}$ Roi des Belges; sa vie Militaire et Politique. Bruxelas, Sand e Leipzig: C. Muquardt, 1850. Disponível em:

<https://books.google.com.br/books?id=0qRBAAAAYAAJ\&hl=pt-BR\&source=gbs_navlinks_s >. Acesso em: 27/10/20.

RASTOUL, A. Sathaniel. La Presse, 13/12/1836.

RAYBAUD, L. “Algérie. Colonies Agricoles. Rapport de M. Louis Raybaud au nome de la commission d'inspection des colonies agricoles de l'Algérie". In: Revue de l'Orient de l'Algérie et des colonies.

"Mouvement et progrès des races humaines, par M. L. Raybaud". Journal des travaux de la Société Française de Statistique Universelle, pour la Société Française de Statistique Universelle. Paris: Bureaux de la Société de Statistique Universelle, v. 7, Bureaux de la Société de Statistique Universelle, 1837, p. 13. Disponível em:

$<$ https://books.google.com.br/books?id=SrJBAAAAcAAJ\&pg=PA13\#v=onepage\&q\&f=false >. Acesso em 20/10/20.

Revue de Paris, Tomo 45. Paris: Au Bureau de la Revue de Paris, 1832, p. 59. Disponível em: <https://books.google.com.br/books?id=3EtFAAAAYAAJ\&pg=RA1-PA59\&lpg=RA1PA59\#v=onepage \&q\&f=false $>$. Acesso em 20/10/20.

SAINTE-BEUVE, C.-A. De la littérature industrielle. Revue des Deux Mondes, Paris, setembro, p. 675-691, 1839.

SAINTINE, M.X.-B. Picciola, door X. Boniface Saintine. Uit het fransch. Dordrecht: P. Los, 1837.

Picciola. Bruxelles: Société Typographique Belge, 1837. Disponível em: https://numelyo.bm-lyon.fr/f_view/BML:BML_00GOO0100137001100262968. Picciola. Huitième édition. Paris: Ambroise Dupont, 1838. Disponível em: https://gallica.bnf.fr/ark:/12148/bpt6k98091190.r=picciola?rk=85837;2. Acesso em 18/09/2020. Picciola. Versão portugueza por Francisco Ladislau Alvares d'Andrada. Paris: Na Imprensa de W. Remquet, Goupy e Ca. 1862. Disponível em: https://gallica.bnf.fr/ark:/12148/bpt6k9364327?rk=85837;2 SOULIÉ, F. Sataniel: novela histórica. Barcelona: Imp. Juan de Oliveres, 1843. Disponível em: 〈http://bdh-rd.bne.es/viewer.vm?id=0000178054\&page=1>. Acesso em: 27/10/20. 
. Sathaniel. Bruxelas: Jamar, 1836.

Sathaniel. Bruxelas: Société Belge de Librairie, etc. Haiman, Cattoir et Comp ${ }^{\mathrm{e}}$, 1837. Disponível em: <https://books.google.com.br/books?id=8XQGAAAAQAAJ\&hl=ptBR\&source=gbs_navlinks_s $>$. Acesso em: 27/10/20.

. Sathaniel. Nouvelle édition, revue et corrigée. Paris: Charles Gosselin, 1841.

Disponível em:

$<$ https://books.google.com.br/books?id=Qc15J4lwUa0C\&dq=Sathaniel+fr\%C3\%A9d\%C3\% A9ric+souli\%C3\%A9\&hl=pt-BR\&source=gbs_navlinks_s $>$. Acesso em: 27/10/20.

. Sathaniel: historischer Roman. Braunschweig: Meyer, 1838.

. Une Couronne d'Épines, par M. Michel Masson. Le Notaire de Chantilly, par M. Léon Gozlan. La Presse, 29/09/1836.

. “Du Roman. Riche et Pauvre. Picciola.”. La Presse, 9 jan. 1837.

THÉRENTY, M.-È. “Avant-propos”. Romantisme, v. 2, n. 136, p. 3-13, 2007. Disponível em: <https://www.cairn.info/revue-romantisme-2007-2-page-3.htm>. Acesso em: 18/09/20. Ver também MANCEAU, N. “Gozlan, Leon”. Nota do Dicionário de Historiadores da Arte. Disponível em: <https://www.inha.fr/fr/ressources/publications/publicationsnumeriques/dictionnaire-critique-des-historiens-de-l-art/gozlan-leon.html>. Acesso em: 18/09/20.

Pour une histoire littéraire de la presse au XIXe siècle. Revue d'histoire littéraire de la France, v. 103, n. 3 , p. 625-635, 2003.

THÉRENTY, M.-È.; VAILLANT, A. 1836: L'An I de l'ère médiathique. Paris: Nouveau monde éditions, 2001.

WATELET, J. “Émile de Girardin ou le premier des "patrons de presse””. In: CHARTIER, R.; MARTIN, H.-J. (org). Histoire de l'édition française - Le temps des éditeurs: du romantisme à la Belle Epoque. Paris: Fayard/Promodis, 1990. 